\title{
Adolescent support networks in a health care context: the interface between health, family and education*
}

\author{
Redes de apoio ao adolescente no contexto do cuidado à \\ saúde: interface entre saúde, família e educação \\ Redes de apoyo al adolescente en el marco del cuidado \\ sanitario: interfaz entre salud, familia y educación
}

Rachel Franklin da Costaํㅜ, Regina Célia Gollner Zeitoune ${ }^{1}$, Maria Veraci Oliveira Queiroz², Carmen Isabel Gómez García ${ }^{3}$, Maria Jesús Ruiz García ${ }^{3}$

* Extracted from the thesis "Cuidado à saúde na percepção dos adolescentes: contribuição da enfermagem", Escola Anna Nery, Universidade Federal do Rio de Janeiro, 2014.

${ }^{1}$ Universidade Federal do Rio de Janeiro, Escola Anna Nery, Rio de Janeiro, RJ, Brazil.

${ }^{2}$ Universidade Estadual do Ceará, Faculdade de Farmácia, Odontologia e Enfermagem, Fortaleza, CE, Brazil.

${ }^{3}$ Universidade de Múrcia, Espinardo, Múrcia, Spain.

\section{ABSTRACT}

Objective: Analyze adolescents' perceptions about support networks and their health needs. Method: Analytical and interpretive study using focus groups conducted in municipal state schools in Fortaleza, in the State of Ceará during the first semester of 2012. The sample comprised 36 male and female adolescents aged between 13 and 16 years attending the ninth grade of the second phase of elementary school. Results: Thematic analysis revealed that the health care support network and interaction between health professionals, education professionals and family members was insufficient, constituting a lack of an integrated network to enable and provide support for health promotion. Conclusion: Coordination between education, health and family services has the potential to act as a support network to help meet adolescents' healthcare needs and demands.

\section{DESCRIPTORS}

Adolescent; Delivery of Health Care; Adolescent Health Services; Social Support; Nursing; Education. 


\section{INTRODUCTION}

Adolescence is one of the most important stages of human development; a time of transition involving intense physical growth and development which invokes feelings of strangeness and uncertainty, accompanied by physiological, psychological and social changes ${ }^{(1)}$. These characteristics can have an important influence on the quality of health care delivered at the different levels of the health care system ${ }^{(2)}$.

Despite intense institutionalization, government policies targeting adolescents and young people remain limited in their capacity to guarantee comprehensive health care for this segment of the population, especially given the specificities of their health care demands. This reality is evidenced by data that show important trends in morbidity and mortality among this group.

The Adolescent Health Program (Programa de Saúde do Adolescent-PROSAD), created in 1989, and the Statute on Children and Adolescents (Estatuto da Criança e do Adolescente), which came into effect in 1990, are the main policies that guide health care and social protection for adolescents in Brazil ${ }^{(3)}$. However, despite these projects, the integral approach and the action of the young protagonist are still lacking, possibly for reasons related to operational components, in other words, difficulties for its implementation, such as the lack of intersectoral action.

Adolescents have the potential to be agents of their own change by participating in actions to promote their integral development and ensure the effectiveness of self-care and health promotion ${ }^{(4)}$. Understanding the health demands and needs of adolescents is therefore important for informing care improvement strategies that involve young people as protagonists in health promotion.

Support networks foster social development, adolescent protection and the development of active citizenship. Being part of such networks reduces the risks and uncertainties involved in coping with personal, social and political crises ${ }^{(5)}$ and enables individuals to understand reality from a more integrated and holistic perspective ${ }^{(6)}$. Support networks constitute a set of connections and interrelationships and express the complexity of the society in which we live and its multicausal and multidependent facts ${ }^{(5)}$.

Support networks are important resources for health care. Health protection and promotion involves building social bonds and relationships of solidarity among individuals and groups. Nurses, together with other health professionals, can play a potentially important role in influencing health behaviors and developing strategies to promote healthy family and community life, and should act as a source of support and social protection for children and adolescents. Giving that this group is considered vulnerable in certain social and health contexts, policies and collective actions are needed to help reduce risks and improve health and living conditions of adolescents ${ }^{(7)}$. In this respect, social support networks have a significant impact on the behavioral change process among adolescents ${ }^{(8)}$.

A social support network can be understood as a complex set of relationships between members of a family or a social system, such as a school, or health or social service organization. They are important tools for protecting and promoting the health of adolescents and the population as a whole. The concept of network is expressed by intentional interaction and coordination between individuals and groups, principally as an organizing strategy to help social actors and agents realize the potential of initiatives to promote the personal and social development of children, adolescents and families ${ }^{(9)}$. In a complex reality, support networks diffuse new values, skills and processes that are important for conducting social action ${ }^{(9)}$.

This study aimed to analyze the perceptions of adolescents on the support networks of their health needs. Its justified by the importance of discussing with them the possibilities that the support networks represents to their social and intellectual development, given adolescents' natural predisposition towards group interaction and need to receive support from those who are part of their daily lives. Besides, the study may indicate important points to be addressed and incorporated into adolescent care practices.

\section{METHOD}

This article presents the results of an analytical and interpretive study drawing on Edgar Morin's complexity theory ${ }^{(6)}$, which views reality as a common thread that creates an inseparable link between an individual and his/her context.

The study was conducted with 36 male and female adolescents attending three state municipal schools located in Health Region IV of the municipality of Fortaleza in the State of Ceará, Brazil, using the following inclusion criteria: participants had to be undergoing the second phase of elementary school and aged between 10 and 19 years. Participants were chosen using snowball sampling, a technique in which the initial participants of a focal group suggest other potential participants ${ }^{(10)}$.

The sample was initially composed of pupils who spontaneously expressed their interest to participate in the study during classroom presentations mediated by the schools' principals. These pupils subsequently suggested other potential participants who were approached to complete the sample. Formal consent was obtained from the pupils and their parents or guardians through the signing of a free, prior and informed consent form.

The sample comprised three focus groups (one in each school), each consisting of 12 members, in order to obtain an adequately representative sample and ensure data quality, based on the understanding that in qualitative research appropriate sample size is determined by selection criteria that do not include a measure of the events being studied. However, care should be taken to obtain the answers to the questions raised by the study ${ }^{(11)}$. Subsequent analysis determined that it was not necessary to increase the number of participants or focus groups. The number of participants was considered adequate, given that the questions presented to the adolescents and the answers they gave were consistent with the study's objectives. The participants had certain common characteristics and, when encouraged, expressed their perceptions of the focal theme of the questions. 
Sample members were aged between 13 and 16 years and the majority of the group were male. Three of the adolescents worked outside school hours: one handed out pamphlets, another was shelve stacker in a supermarket, while the other was a salesperson in a cellphone shop. With respect to the adolescents who did not work, 16 were doing other courses outside school, including a preparatory course for the army selection process, web design, computing, chemistry, and pró-médio, a project implemented by the town council to reduce the shortfall in the number of municipal school pupils approved in the entrance exams of the Centro Federal de Educação Tecnológica do Ceará (CEFET), a federal secondary technical college. Nineteen adolescents lived with their parents and siblings, 13 lived with one of their parents, while the rest lived with other relatives. With respect to parents' schooling, the majority of parents had completed only the first phase of elementary school and none of the parents had completed higher education.

After collecting personal data, the objective of the focus group was clearly explained together with the questions that were going to be discussed and rules, including the participation of each member and the role of the moderator ${ }^{(12)}$. The moderator led the discussion and encouraged the group to talk about the following topics: health, health care and adolescent support networks. The date and time of the meetings were previously scheduled with the adolescents and the discussions lasted between one and a half and two hours, depending on each group's needs. The discussions were recorded using a digital recorder, transcribed, organized and interpreted using thematic analysis ${ }^{(13)}$ in three steps: preanalysis, material exploration, processing of results, and interpretation. Subsequently we extracted meaningful groups, obtaining the following analytical category: support networks as a health/family care need, health professional, education professionals and government.

With respect to ethical concerns, the study participants were informed about the research objectives, risks and benefits, type of participation and contribution to the reality of participants. Participants were guaranteed confidentiality and the right to withdraw from the study at any time without any loss or damage. To protect confidentiality and privacy, each adolescent chose a fictitious name and the real name of participants was not divulged at any time. The study therefore met the requirements of Resolution 196/96 concerning research involving human beings and was approved by the Ethics Committee (reference number 102/2011).

\section{RESULTS}

Support networks as a health/family care need, health professional, education professionals and government.

The content of this analytical category suggests that the family nucleus is a source of support for the majority of adolescents, who reported that they generally sought health services accompanied by one of their parents. Some mentioned difficulties in accessing services due to the distance between the health facility and their home, or because they often failed to receive treatment from a health professional. Family support and structure were therefore linked to health care in the form of a health care support network.
Health care needs come from the family structure because it is through this structure that various diseases are prevented through its teachings. That's what the doctors say most; that the family structure, and well-being, you feeling good with yourself, avoids various physical and mental illnesses. So, it's the lack of family structure (Emília).

The adolescents highlighted the need for care related to physical health aspects, particularly disease prevention, represented by medical care.

Go to the doctor, know how you are, take care of your body, have a checkup (...) (Olivia).

I you are feeling pain and it doesn't go away, you have to go to the doctor. You have to take care of your health, because it's really important (Minnie).

It's self-examining yourself, going to the doctor, because perhaps you are sick and you don't even know it. So you should go and have an examination and discover an illness that you didn't even know you had (Ub).

Have medical examination each year and go to hospital (Asuma).

The adolescents mentioned the lack of health professionals and a multidisciplinary team to meet their health needs and provided care, whether in primary care facilities or hospitals. They also mentioned the need for professional training to address the specificities of this phase of life and attentiveness to subjectivities.

There should be more types of health professionals in health centers and hospitals, because there aren't many and the main area is only pediatrics, emergency, minor surgeries and that's it. You never find a psychologist (...) So there is a lack of health professionals in health centers and hospitals (Jack Chan).

There should be a female doctor who lets adolescents feel more comfortable, who talks about various other health issues. Every time you go into the doctor's room you have to go in with your mum; you can't go in by yourself, be uninhibited in the room and be just you there (Chiquinha).

I think that it's being treated well and having more qualified professionals to look after you (Wendy).

Home visits promoted by the Family Health Strategy (Estratégia Saúde da Família - ESF) that encourage communication between health users and health professionals is a potential strategy of the health promotion support network and could strengthen bonds between professionals and service users as the following comments show:

Doctors should visit people in real need at home so they can be treated daily. Visit the homes of people in need. I think that's what care needs are (Daphne). 
There should be professionals that visit our houses

to provide information (...) (Tinker Bell)

When mentioning education professionals as an element of the support network, the participants added that shared actions with these professionals to ensure a comprehensive assessment of adolescents could prove to be an important health promotion support network.

More doctors should come to the schools to reduce the queues in the health centers for us to be seen (Chiquinha).

I think we should have a mini health center in the schools to improve that school's pupil's health (Jade).

It would be good if every school had a doctor; a lot of accidents in the schools take ages to be seen in the hospital. We don't have medicines. Just doctors? A lot of hospitals have nurses, but the nurses can't look after everyone (Nemo).

[health professionals] Coming here to the school is a health care need. Before we had teeth brushing and now it's stopped, so it's a need (Daphne).

The adolescents also mentioned government indifference to protection and care networks that could be organized to meet needs.

\section{I think that adolescents need to do sport. I think that the government should do some projects to encourage adolescents to do sports (Goku).}

What's the point of someone who is poor wanting to be healthy if the government doesn't help? We have to wait in the queue at the health center in the middle of the night and it's getting worse and worse (Wendy).

The city council doesn't care about adolescent health. They should think about health as well and not just in the beauty of the cities, because there are people that are ill, not well and dying (Tinker Bell).

The comments made by the adolescents also showed that their needs are neglected and that there is a lack of interaction between health professionals, schools, health facilities and the family, which could represent a shortcoming of the social protection and health care network.

I think the school should participate more in our life. I think that it would change things a lot because, for example, I don't think they care if something happens at home and I show up here with bruises. A group like this one would be interesting for us to debate things. A reading group. There's nothing like that here (Ariel).

I think that the school should have a psychologist because there are a lot of people here who I know don't open up much to their family because they are scared, retaliation... So the school should have someone who we can trust, to open our heart to and say what we feel (Nemo).
The interaction with these adolescents gave us an insight into their health care needs. Being heard in social, educational and health environments was one of the needs highlighted.
Me, as a pupil, I can give my opinion, but a lot of people don't listen to an adolescent. I think they are really irresponsible and don't know what they are doing. But it they gave us a chance to say what we think, then they would see that we are serious (Tinker Bell).

\section{DISCUSSION}

Meanings related to the family nucleus as an informal health care support network emerged during the discussion with the adolescents, confirming the socio-historical construction of a system of reference composed of primary social interactions; an independent fabric between the parts and the whole that influences health care education ${ }^{(6)}$.

Since human beings are innately social and seek out interpersonal relationships, they use social and affective support networks for coping with and solving the problems that arise during life. During moments of personal crisis, the family is the primary network to which an individual turns to for support and informal care ${ }^{(14)}$. It is within this environment that the first social and affective relationships are established and in which an individual finds the educational measure to structure identity.

Adolescence is a phase that involves transformations in both the adolescent and the family, the latter of which must adapt to this moment in the life cycle of its members. The role of the family is to provide a source of security, affection, protection and well-being; functions that, depending on the situation, it is not always able to fulfil ${ }^{(15)}$. When families are unable to provide adequate support, secondary networks, composed of formal relations with different types of services, including the health service, can help fill the gap ${ }^{(14)}$. However, these networks are generally insufficient to meet the care needs of these individuals and groups ${ }^{(5)}$.

The government should create and effectively implement policies to guarantee the right to health care and ensure social protection, particularly for socially vulnerable groups. There is a need to mobilize and coordinate effective social support networks that are capable of protecting adolescents and minimizing the risks to adolescent health. The adolescent and Young People's Health Department of the Ministry of Health is promoting and aligning a new perspective on adolescence and youth which is capable of identifying specific needs and defining responsibilities in the public health sphere ${ }^{(3)}$.

Brazil has made considerable investments in social and health policies and in the formulation of guidelines and goals to ensure comprehensive care for adolescents. However, these proposals are not effectively implemented in practice because of the shortage of health professionals necessary to ensure interventions necessary to deliver effective health services ${ }^{(16)}$. 
The discussion about support networks shows that the adolescents have a fragmented perception of health services, since when they talk about prevention and care actions they emphasize the doctor as the main actor, without mentioning the other health professionals who work in health facilities such as nurses. It is therefore important to highlight the important role that each type of health professional plays within the health services and thus their potential contribution as a support network for those who seek these services.

Within a wider concept of network, public services should seek to meet the geographical pattern and collective nature of demands, expanding to include participation and collective construction ${ }^{(5)}$. The Statute on Children and Adolescents suggests a need for coordinated public actions to ensure the comprehensive protection of this segment of the population, which are capable of promoting relationships, links and coordination between different services to guarantee effectiveness ${ }^{(9)}$.

It is also interesting to note that the adolescents' comments show that their voices are often not heard during the course of health promotion actions intended to support the development of healthy social relations and habits. The support networks idealized by these adolescents constitute a process that involves family, friendship and sharing relationships established through social interaction, as well as public mechanisms capable of meeting their needs, including the delivery of quality care by qualified professionals. Integrated actions would certainly help to meet these objectives. To provide comprehensive care in practice, professionals must take an interdisciplinary approach that promotes access to quality care that meets the needs of adolescents and focuses on providing a welcoming environment and establishing bonds ${ }^{(16)}$.

An interdisciplinary approach promotes dialogue, which in turn stimulates ideas and, consequently, joint intellectual development to improve people's health. However, health professionals have an increasingly narrow view of health and disease and are unable to conceive health from a more holistic perspective. Interdisciplinarity creates the possibility of cooperation and exchange through common projects and objectives ${ }^{(6,17)}$. The absence of this approach in the care provided to these adolescents indicates that the health and education professionals have not presented themselves to these individuals as a support network, meaning that the adolescents do not see them as a point of reference in the search for health care guidance.

Effective health promotion requires professionals to interact with young patients and immerse themselves in their daily lives, since many of their needs are invisible in the face of other priorities. It is necessary to create dialogue to identify adolescents' health needs ${ }^{(18)}$.

With respect to health care, it is interesting to note how much adolescents express their expectations when it comes to meeting their health care needs. To meet these needs adolescents must participate in primary health services. In this respect, widening access aims to promote the consolidation of comprehensive health care for adolescents ${ }^{(19)}$.
These adolescents express a demand for care that goes beyond the limits of the health facility, specifically mentioning the home. Home visits are an interaction technology used in family health care and a way of facilitating health actions to reduce inequalities. They bring the service closer to the needs of families and, at the same time, promote autonomy, since they favor dialogue and exchange of knowledge ${ }^{(20)}$. When conducted within an interdisciplinary approach, home visits can represent a support network that addresses the demands of adolescents.

Another alternative suggested by the participants to improve access, strengthen bonds and to meet the needs of adolescents relates to care provided by the schools. When support networks are unable to help them with typical conflicts during this phase, adolescents become more vulnerable to frustration, psychosocial risks, violent behavior and other personal and social difficulties. Therefore, social and affective support networks help adolescents to adapt to their social environment ${ }^{(21)}$.

The School Health Program (Programa Saúde na Escola -PSE) provides a clinical and psychosocial examination for children, adolescents and young people at least once a year (preferably at the beginning of the school year) and offers comprehensive care according to the health needs detected by the examination ${ }^{(22)}$. The school has become an important setting for health promotion by stimulating autonomy, exercising rights and duties, and influencing health conditions and quality of life ${ }^{(22)}$.

Multiprofessionalism is critical for developing citizens who are able to think critically and who are more secure in themselves, and for promoting healthy behaviors. By networking with other sectors of society, the family and school contribute towards the physical, emotional and social development of adolescents, allowing them to feel secure with their health choices.

Give that adolescents and young people tend to seek their identity and answers to their concerns in their peer group, it could be suggested that group care could help professionals to address the difficulties raised by adolescents, deal with problems such as depression, and improve adhesion to the advice and guidance provided by the health team ${ }^{(23)}$.

The involvement of professionals from various backgrounds enables the exchange of ideas, provides support and contributes to the education of these young people. However, it is evident that primary care gives little consideration to the experiences and possible autonomy of adolescents within a context of vulnerability and health risk. To tackle this problem, it is necessary to bring health care more in line with adolescents' health needs and how they problematize and cope with situations of vulnerability. The ESF and PSE should promote a discussion of issues related to adolescent health care in schools, particularly in poorer regions and where the prevalence of working during adolescence is higher ${ }^{(24)}$.

Also with respect to care, the adolescents commented that education professionals do not notice signs of physical violence and suggest the promotion of discussions and the presence of professionals with listening skills. 
It is important to highlight that school is an extremely important institution to these adolescents, who suggest that its role should go beyond teaching to include health protection and promotion. However, given the context of violence, the school has certain difficulties in fulfilling the role given to it by the adolescents ${ }^{(7)}$.

A study conducted in Australia analyzing the social and emotional characteristics of children and issues related to violence, showed how important the presence of a multiprofessional team is, highlighting the role of nurses in the school environment and their importance for the social and emotional development of pupils related to health and learning ${ }^{(25)}$.

The support of family members, educators, health professionals and peer groups participating in educational projects constitutes an important adolescent health support network, helping them to overcome the challenges associated with typical physical, emotional, and social transformations during this phase, and contributing towards their personal and social development and autonomy in choice and decision-making.

\section{CONCLUSION}

The analysis of adolescents' perceptions of support networks and their health needs shows that this group sees the family as the main source of support and guidance. However, the participants perceived health professionals as a support network, often in association with the school, despite the shortcomings highlighted by the adolescents in meeting their expectations.

Public policies should promote the creation of informal secondary networks to effectively implement actions targeting this growing segment of society, given that the family alone is not able to meet adolescents' needs and demands. Many adolescents require support outside the family and school environment to cope with the physical, emotional, and social transformations associated with this phase, including the formation of identity and development of autonomy. Some adolescents highlighted the need for professional competence to deliver care and an interdisciplinary approach that, through effective listening, is attentive to the subjectivities of adolescence.

Providing a welcoming environment and ensuring their voices are heard is critical for determining needs and enhances social and emotional support, thus strengthening individual resources for coping with the adversities associated with this age. These strategies are crucial to ensure effective health promotion for adolescents and encourage healthy behaviors.

\section{RESUMO}

Objetivo: Analisar as percepções dos adolescentes sobre as redes de apoio a suas necessidades de saúde. Método: Estudo analítico interpretativo, realizado em escolas do Município de Fortaleza, CE, no primeiro semestre de 2012, por meio de grupos focais. Os sujeitos da pesquisa foram 36 adolescentes de ambos os sexos com idades entre 13 e 16 anos e que cursavam o $9^{\circ}$ ano do ensino fundamental II. Resultados: A análise por categorização temática permitiu a compreensão do fenômeno, revelando que a rede de apoio aos cuidados à saúde dos adolescentes e a inter-relação entre os profissionais da saúde, da escola e familiares é insuficiente, configurando a ausência de uma rede integrada que favoreça e dê suporte à promoção de sua saúde. Conclusão: A articulação entre os setores educacional, familiar e de saúde pode funcionar como rede de apoio às necessidades e demandas de cuidados dos adolescentes.

\section{DESCRITORES}

Adolescente; Assistência à Saúde; Serviços de Saúde do Adolescente; Apoio Social; Enfermagem; Educação.

\section{RESUMEN}

Objetivo: Analizar las percepciones de los adolescentes acerca de las redes de apoyo a sus necesidades de salud. Método: Estudio analítico interpretativo, llevado a cabo en escuelas del Municipio de Fortaleza, CE, en el primer semestre de 2012, por medio de grupos focales. Los sujetos de la investigación fueron 36 adolescentes de ambos sexos con edades entre 13 y 16 años y que cursaban el último año de la educación básica brasileña. Resultados: El análisis por categorización temática permitió la comprensión del fenómeno, desvelando que la red de apoyo a los cuidados sanitarios de los adolescentes y la interrelación entre los profesionales sanitarios, la escuela y los familiares es insuficiente, configurándose la ausencia de una red integrada que favorezca y dé soporte a la promoción de su salud. Conclusión: La articulación entre los sectores educativo, familiar y sanitario puede funcionar como red de apoyo a las necesidades y demandas de cuidados de los adolescentes.

\section{DESCRIPTORES}

Adolescente; Prestación de Atención de Salud; Servicios de Salud del Adolescente; Apoyo Social; Enfermería; Educación.

\section{REFERÊNCIAS}

1. Silveira RE, Reis NA, Santos AS, Borges MR, Soares SM. Oficinas com adolescentes na escola: uma estratégia de educação em saúde. Nursing (São Paulo). 2011;14(157):334-8.

2. Penna LHG, Rodrigues RF, Lucido VA, Guedes CR, Lima LMA. Care of adolescents sheltered in maternity hospitals from the perspective of health professionals. Acta Paul Enferm. 2012;25(2):121-7.

3. Lopez SB, Moreira MCN. Quando uma proposição não se converte em política? O caso da Política Nacional de Atenção Integral à Saúde de Adolescentes e Jovens - PNAISAJ. Ciênc Saúde Coletiva. 2013;18(4):1179-86.

4. Betancurth DP, Vélez C. La adolescencia: un reto para los profesionales de la salud. Cult Cuid Enferm. 2012;9(2):50-63. 
5. Gonçalves AS, Guará IMFR. Por uma nova cultura de articulação e cooperação em rede. In: Guará IMFR, coordenadora. Redes de proteção social. São Paulo: Associação Fazendo História; 2010. p.11-28.

6. Morin EA. Cabeça bem feita: repensar a reforma, reformar o pensamento. 18 ${ }^{\mathrm{a}}$ ed. Rio de Janeiro: Bertrand Brasil; 2010.

7. Carlos DM, Ferriani MGC, Esteves MR, Silva LMP, Scatena L. Social support from the perspective of adolescent victims of domestic violence. Rev Esc Enferm USP [Internet]. 2014 [cited 2014 Oct 12];48(4):610-7. Available from: http://www.scielo.br/pdf/reeusp/v48n4/0080-6234reeusp-48-04-610.pdf

8. Sales AE, Estabrooks CA, Valente TW. The impact of social networks on knowledge transfer in long-term care facilities: protocol for a study. Implement Sci. 2010;5:49.

9. Guará IMFR, coordenadora. Redes de proteção social. São Paulo: Associação Fazendo História; 2010.

10. Baldin N, Munhoz EMB. Educação ambiental comunitária: uma experiência com a técnica de pesquisa snowball (bola de neve). Rev Eletr Mestr Educ Ambient [Internet]. 2011 [citado 2014 jun.15];27(1):46-60. Disponível em: http://www.seer.furg.br/remea/article/ view/3193/1855

11. Fontanella JB, Luschesi BM, Saidel MGB, Turato ER, Melo DG. Amostragem em pesquisas qualitativas: proposta de procedimentos para constatar saturação teórica. Cad Saúde Pública. 2011;27(2):389-94.

12. Trad LAB. Grupos focais: conceitos, procedimentos e reflexões baseadas em experiências com o uso da técnica em pesquisas de saúde. Physis. 2009;19(3):777-96.

13. Bardin L. Análise de conteúdo. São Paulo: Edições 70; 2011.

14. Faquinello P, Carreira L, Marcon SS. A unidade básica de saúde e sua função na rede de apoio social ao hipertenso. Texto Contexto Enferm. 2010;19(4):736-44.

15. Patias ND, Gabriel MR, Dias ACG. A família como um dos fatores de risco e de proteção nas situações de gestação e maternidade na adolescência. Estudos Pesq Psicol. 2013;13(2):586-610.

16. Costa RF, Queiroz MVO, Zeitoune RCG. Cuidado aos adolescentes na atenção primária: perspectivas de integralidade. Esc Anna Nery. 2012;16(3):466-72.

17. Morin E. Ciência com consciência. Rio de Janeiro: Bertrand Brasil; 2010.

18. Horta NC, Sena RR. The everyday health of the young individuals of a popular neighborhood of Belo Horizonte, Minas Gerais, Brazil. Rev Esc Enferm USP [Internet]. 2011 [cited 2014 June 15];45(n.spe2):1673-78. Available from: http://www.scielo.br/pdf/reeusp/v45nspe2/ en_06.pdf

19. Vieira RP, Gomes SHP, Machado MFAS, Bezerra IMP, Machado CA. Participation of adolescents in the Family Health Strategy from the theoretical-methodological structure of an enabler to participation. Rev Latino Am Enfermagem. 2014;22(2):309-16.

20. Cruz MM, Bourget MMM. A visita domiciliária na Estratégia de Saúde da Família: conhecendo as percepções das famílias. Saúde Soc. 2010;19(3):605-13.

21. Penso MA, Brasil KCTR, Arrais AR, Lordello SR. A relação entre saúde e escola: percepções dos profissionais que trabalham com adolescentes na Atenção Primária à Saúde no Distrito Federal. Saúde Soc. 2013;22(2):542-53.

22. Brasil. Ministério da Saúde; Secretaria de Atenção à Saúde, Departamento de Atenção Básica. Saúde na escola [Internet]. Brasília; 2009 [citado 2014 jun. 15]. Disponível em: http://dab.saude.gov.br/docs/publicacoes/cadernos_ab/abcad24.pdf

23. Kanno NP, Bellodi PL, Tess BH. Profissionais da Estratégia Saúde da Família diante de demandas médico-sociais: dificuldades e estratégias de enfrentamento. Saúde Soc. 2012;21(4):884-94.

24. Reis DC, Almeida TAC, Miranda MM, Alves RH, Madeira AMF. Health vulnerabilities in adolescence: socioeconomic conditions, social networks, drugs and violence. Rev Latino Am Enfermagem [Internet]. 2013 [cited 2014 June 15];21(2):586-94. Available from: http://www. scielo.br/pdf/rlae/v21n2/0104-1169-rlae-21-02-0586.pdf

25. Nelson H, Kendall G, Shields L. Children's social/emotional characteristics at entry to school: implications for school nurses. J Child Health Care. 2013;17(3):317-31. 